\title{
A species-specific population of tyrosine hydroxylase-immunoreactive neurons in the medial amygdaloid nucleus of the Syrian hamster
}

\author{
Stephen E. Asmus, Anthony E. Kincaid and Sarah Winans Newman \\ Department of Anatomy and Cell Biology, Medical Science Building II, University of Michigan, Ann Arbor, MI 48109 (U.S.A.)
}

(Accepted 5 November 1991)

Key words: Tyrosine hydroxylase; Dopamine; Immunocytochemistry; Colchicine; Amygdala; Syrian hamster; Chemosensory pathway

\begin{abstract}
The medial amygdaloid nucleus (Me) is part of a neural pathway that regulates sexual behavior in the male Syrian hamster. To characterize the neurochemical content of neurons in this nucleus, brains from colchicine-treated adult male and female hamsters were immunocytochemically labeled using antibodies that recognize the catecholamine-synthesizing enzymes, tyrosine hydroxylase (TH), dopamine- $\beta$-hydroxylase (DBH) and phenylethanolamine- $\mathrm{N}$-methyltransferase (PNMT), as well as dopamine: A large population of TH-immunoreactive (TH-IR) neurons was observed throughout Me of male and female hamsters, primarily concentrated in the midrostral and caudal portions of the nucleus. The somata were generally small to medium in size and bipolar. Brains from animals that did not receive colchicine contained a limited number of TH-IR neurons in Me as reported previously. The DBH and PNMT antisera did not label any cells in Me of colchicinetreated animals, and the dopamine antiserum labeled neurons in the same location as the caudal group of TH-IR cells. Therefore, these caudal TH-IR neurons are interpreted to be dopaminergic. The rostral group of TH-IR neurons, on the other hand, may be producing only the immediate precursor of dopamine, L-3,4-dihydroxyphenylalanine (L-DOPA). The TH-synthesizing neurons in Me of the Syrian hamster appear to be a species-specific group of cells located outside of the previously described catecholaminergic cell groups.
\end{abstract}

\section{INTRODUCTION}

The distribution of catecholaminergic neurons in the rat brain has been well-characterized immunocytochemically using antibodies against tyrosine hydroxylase $(\mathrm{TH})^{21-23}$, the first and rate-limiting enzyme in the catecholamine biosynthetic pathway ${ }^{39,49}$. TH-immunoreactive (TH-IR) neurons have also been identified outside of the previously reported catecholaminergic cell groups in the telencephalon of a variety of species, including

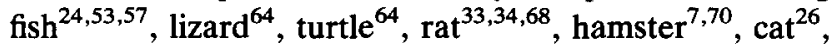
non-human primate ${ }^{10,30}$, and human ${ }^{15,16}$. The male Syrian hamster (Mesocricetus auratus) is the only species in which TH-IR neurons have been reported in the medial nucleus of the amygdala $(\mathrm{Me})^{7,70}$.

The medial amygdala plays an essential role in the regulation of male hamster sexual behavior ${ }^{37,38}$. As part of the neural pathway that controls reproduction, this nucleus is the first point at which vomeronasal, olfactory, and hormonal information is integrated ${ }^{9,17,37,38}$. Several putative neurotransmitters have been identified immunocytochemically in somata within $\mathrm{Me}$, including substance $\mathrm{P}^{58}$, cholecystokinin $(\mathrm{CCK})^{58,61}$, somatostatin ${ }^{13,58}$, vasopressin $^{3,65}$, vasoactive intestinal polypeptide ${ }^{41}$, and enkephalin ${ }^{25}$ in the rat and substance $\mathrm{P}^{51,67}, \mathrm{CCK}^{44}$ and dynorphin ${ }^{50,51}$ in the hamster. In addition, a sparse number of TH-IR neurons have been identified in $\mathrm{Me}$ in studies of the distribution of TH-IR neurons in the hamster brain ${ }^{7,70}$, indicating that some neurons in this nucleus may also produce catecholamines. In these studies, animals either were not treated with colchicine ${ }^{70}$ or were treated with relatively small doses of the drug $^{7}$ to inhibit axoplasmic transport ${ }^{6,35}$.

The intracerebroventricular (i.c.v.) administration of colchicine is often necessary to visualize peptide-containing cell bodies with immunocytochemistry ${ }^{20,40}$ and has been used occasionally to optimize the identification of TH-IR cells ${ }^{26,27,62}$. Since Davis and Macrides ${ }^{7}$ and Vincent $^{70}$ observed a small number of TH-containing cells in $\mathrm{Me}$ of untreated hamsters, we hypothesized that colchicine treatment would enhance TH immunostaining in this area. Therefore, in this study the brains of colchicine-treated male and female hamsters were utilized to examine the distribution, number and morphology of TH-IR neurons in Me. To determine which of the catecholamines was present in these TH-IR cells, colchinetreated tissue was also incubated with antisera generated against dopamine, or against the enzymes dopamine- $\beta$ hydroxylase (DBH) or phenylethanolamine- $N$-methyltransferase (PNMT), which synthesize norepinephrine 

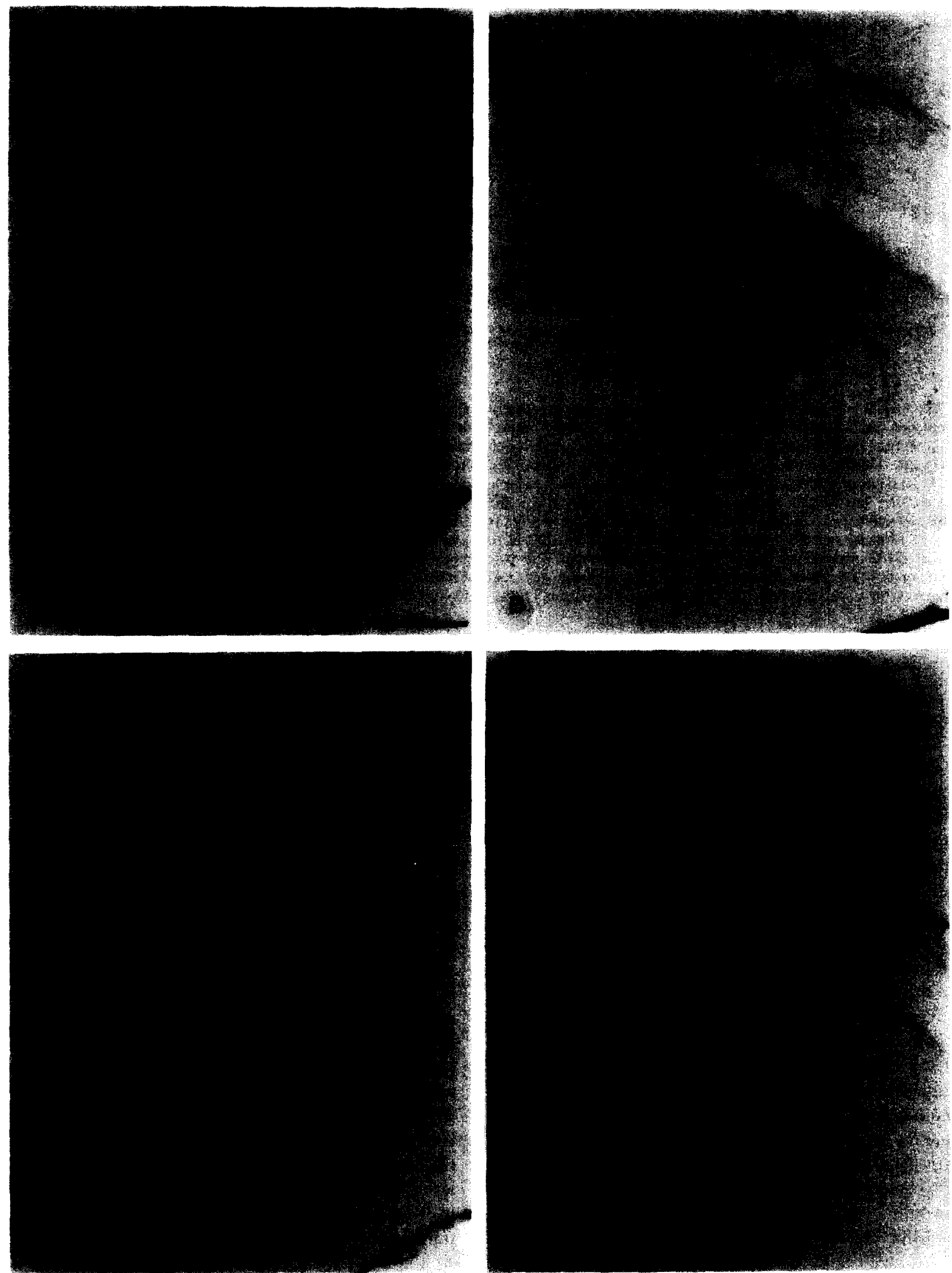

Fig. 1. Photomicrographs of tyrosine hydroxylase-immunoreactive (TH-IR) neurons in the male hamster medial amygdaloid nucleus (Me) immunolabeled with the monoclonal TH antibody. Large populations of TH-IR neurons were observed in midrostral (A) and caudal (B) Me of colchicine-treated brains. Fewer TH-IR neurons were observed in these same areas of noncolchicine-treated brains (C,D). Midrostral Me (A,C) corresponds to the level of Me shown in Fig. 2B, while caudal Me (B,D) corresponds to the level of Me shown in Fig. 2D. In B and $\mathrm{D}$ note the close association of TH-IR neurons with blood vessels (B). LV, lateral ventricle; ot, optic tract. Bar $=200 \mu \mathrm{m}$. 
and epinephrine, respectively.

\section{MATERIALS AND METHODS}

Animals, surgery and preparation of tissue

Twenty six adult Syrian hamsters (91-165 g; Charles River, Wilmington, MA) were group-housed in a $14 \mathrm{~h}$ light:10 h dark illumination cycle and given food and water ad libitum. To compare dosage effects of colchicine on TH immunostaining, various colchicine concentrations were administered. Thirteen male and 4 female animals were anesthetized with sodium pentobarbital $(10 \mathrm{mg} / 100 \mathrm{~g}$ b.wt. i.p.), and were injected stereotaxically into the lateral ventricle with $160 \mu \mathrm{g}(n=2), 200 \mu \mathrm{g}(n=13)$, or $320 \mu \mathrm{g}(n=2)$ of colchicine (Sigma, St. Louis, MO) in either 2 or $2.5 \mu \mathrm{l}$ of distilled $\mathrm{H}_{2} \mathrm{O}$ as described by Neal and Newman ${ }^{50}$. Three additional male animals did not receive colchicine. These 20 animals were used for TH, DBH and PNMT immunocytochemistry. Six male animals were used for dopamine immunocytochemistry. Four of these animals received $200 \mu \mathrm{g}$ of colchicine into the lateral ventricle, and two animals did not receive the drug.

In preparation for $\mathrm{TH}, \mathrm{DBH}$, and PNMT immunocytochemistry, hamsters were deeply anesthetized after a survival period of $48 \mathrm{~h}$ and perfused through the ascending aorta with $150 \mathrm{ml}$ of $0.1 \mathrm{M}$ sodium phosphate buffered saline (NaPBS) with $0.1 \%$ sodium nitrite for vasodilation, followed by $200-250 \mathrm{ml}$ of either $4 \%$ paraformaldehyde in $0.1 \mathrm{M}$ sodium phosphate buffer (NaPB) $(n=18$, including noncolchicine-treated animals) or $2 \%$ paraformaldehyde and $0.25 \%$ parabenzoquinone in $50 \mathrm{mM} \mathrm{NaPB}(n=2)$. The benzoquinone-paraformaldehyde fixative was tested because it had been reported to enhance peptide immunostaining in the hamster limbic system $^{50}$. Brains were postfixed for $1-2 \mathrm{~h}$ in the perfusion fixative and cryoprotected overnight with $20 \%$ sucrose in $\mathrm{NaPB}$ at $4^{\circ} \mathrm{C}$. Coronal sections $(40 \mu \mathrm{m})$, cut on a freezing microtome, were serially collected into $0.1 \mathrm{M} \mathrm{NaPB}$ with $0.01 \%$ sodium azide and stored at $4^{\circ} \mathrm{C}$.

Four colchicine-treated and two noncolchicine-treated animals were prepared for dopamine immunostaining by transcardial perfusion with $100 \mathrm{ml}$ of $2 \%$ sodium chloride and $1 \%$ sodium met- abisulfite in $\mathrm{dH}_{2} \mathrm{O}$ (pH 7.2) followed by $150 \mathrm{ml}$ of $5 \%$ glutaraldehyde and $1 \%$ sodium metabisulfite in $50 \mathrm{mM}$ sodium cacodylate buffer ( $\mathrm{pH}$ 7.6). The brains were removed and blocked into 3-5 $\mathrm{mm}$ slices and postfixed for $1 \mathrm{~h}$ in the perfusion fixative. The tissue was then transferred to a cryoprotectant solution containing $20 \%$ sucrose and $1 \%$ sodium metabisulfite in $50 \mathrm{mM}$ Tris $(\mathrm{pH} \mathrm{7.2)}$ and stored overnight at $4^{\circ} \mathrm{C}$. The cutting and storage procedures were identical to those described above.

\section{Antisera}

The polyclonal $\mathrm{TH}$ antisera were generated in rabbit against $\mathrm{TH}$ purified from either bovine adrenal gland (Eugene Tech Intl., Allendale, NJ) or PC-12 cells (East-Acres Biologicals, Southbridge, MA). The monoclonal TH antibody (Incstar, Stillwater, MN) was raised in mouse against TH purified from PC-12 cells. The DBH and PNMT polyclonal antisera (Eugene Tech Intl.) were raised in rabbit against enzymes purified from bovine adrenal gland. The dopamine antiserum (Eugene Tech Intl.) was raised in rat against dopamine coupled to Limulus hemocyanin by glutaraldehyde. The polyclonal TH, DBH, PNMT and dopamine antisera were used at a dilution of 1:1000, and the monoclonal $\mathrm{TH}$ antibody was used at a dilution of 1:7000. Excellent immunostaining was observed when the monoclonal $\mathrm{TH}$ antibody was diluted up to $1: 50,000$.

\section{Immunocytochemistry}

For TH, DBH and PNMT immunocytochemistry, free-floating brain sections were immunolabeled using a modification of the Sternberger peroxidase-antiperoxidase (PAP) method ${ }^{66}$. After rinsing in either $0.1 \mathrm{M} \mathrm{NaPB}$ or $0.02 \mathrm{M}$ potassium phosphate-buffered saline (KPBS), at least every third section from each brain was incubated with the primary antibody diluted with the same buffer containing $0.3 \%$ Triton-X for $48-60 \mathrm{~h}$ at $4^{\circ} \mathrm{C}$. Sections adjacent to TH-immunostained material from two colchicine-treated brains were incubated with the DBH or PNMT antisera. All subsequent incubations were carried out in KPBS with $0.3 \%$ Triton-X for $1 \mathrm{~h}$ at room temperature. Depending on the host of the primary antiserum, sections were incubated with either donkey anti-rabbit (1:50) or goat anti-mouse (1:100) antiserum, followed by rabbit (1:100) or mouse (1:200) PAP complex (Jackson ImmunoResearch,

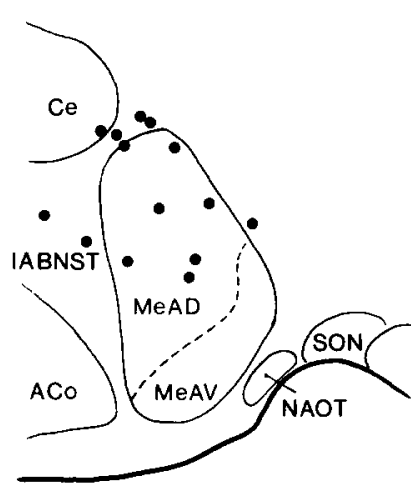

A

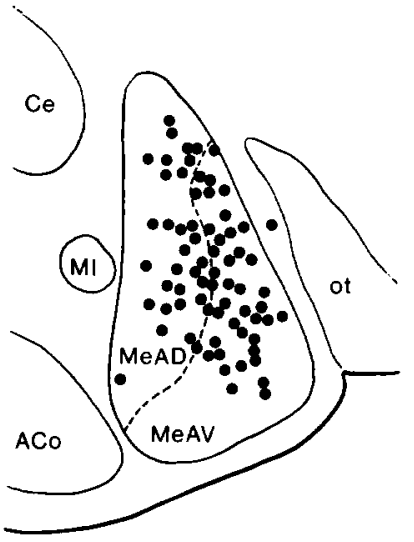

B

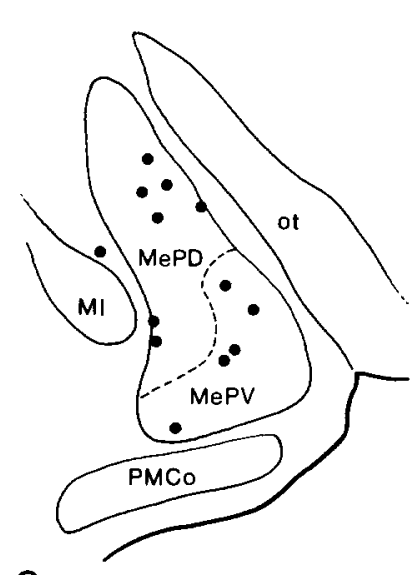

C

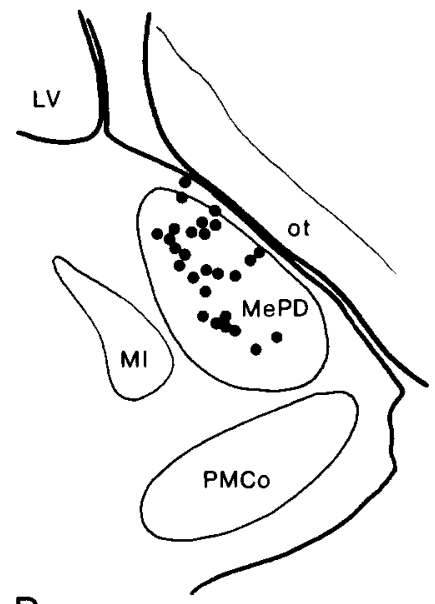

D

Fig. 2. Schematic representations of coronal sections from 4 rostrocaudal levels of Me from a single hamster brain showing the distribution of TH-IR neurons. A: rostral Me; B: midrostral Me; C: midcaudal Me; D: caudal Me. ACo, anterior cortical amygdaloid nucleus; Ce, central amygdaloid nucleus; IABNST, intraamygdaloid bed nucleus of the stria terminalis; LV, lateral ventricle; MeAD, medial amygdaloid nucleus, anterodorsal subdivision; MeAV, anteroventral subdivision; MePD, posterodorsal subdivision; MePV, posteroventral subdivision; MI, massa intercalata; NAOT, nucleus of the accessory olfactory tract; ot, optic tract; PMCo, posteromedial cortical amygdaloid nucleus; SON, supraoptic nucleus of the hypothalamus. 


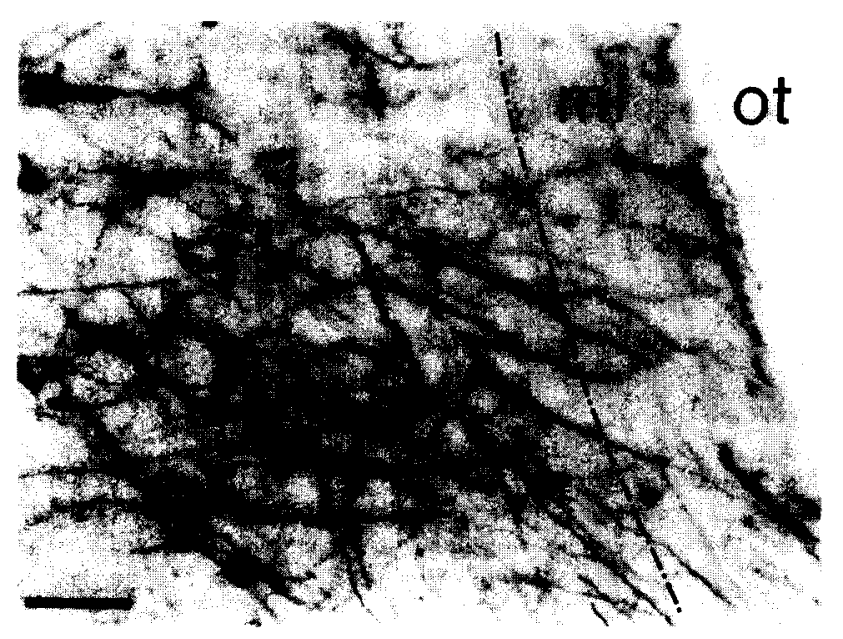

Fig. 3. Photomicrograph of TH-IR neurons in midrostral Me showing the morphological characteristics typical of these neurons throughout the nucleus. Note the dendrites extending into the medial molecular layer $(\mathrm{ml})$ adjacent to the optic tract $(\mathrm{ot})$. Bar $=50$ $\mu \mathrm{m}$.

West Grove, PA). After each incubation, sections were washed 3 times ( 5 min each) in KPBS. Bound peroxidase was visualized by incubation of the tissue in a solution containing $0.0125 \%$ diaminobenzidine tetrahydrochloride (DAB) (Sigma, St. Louis, MO), $0.015 \%$ nickel chloride and $0.06 \%$ hydrogen peroxide in KPBS for 5-10 min. The reaction was stopped in distilled $\mathrm{H}_{2} \mathrm{O}$, and sections were mounted out of KPBS onto gelatin-coated slides, dehydrated, cleared, and coverslipped with Permount. TH-immunolabeled sections from two brains were counterstained with Cresyl violet.

Dopamine immunostaining was carried out by incubating every other section from the glutaraldehyde-fixed brains with the dopamine antiserum diluted with $1 \%$ sodium metabisulfite, $0.5-1 \%$ Triton-X, $0.05 \%$ bovine serum albumin (BSA) and $0.05 \%$ sodium azide in $50 \mathrm{mM}$ Tris $(\mathrm{pH} \mathrm{7.2)}$ for at least $12 \mathrm{~h}$ at room temperature. The tissue was then incubated for $1 \mathrm{~h}$ at room temperature with biotinylated goat anti-rat (Sigma) diluted to $1: 100$ with $0.1 \mathrm{M}$ NaPBS containing $0.05 \%$ BSA, $0.5 \%$ Triton- $X$ and $2 \%$ normal rabbit serum followed by an incubation with the Elite Vectastain avidin-biotin complex solution (Vector Labs, Burlingame, CA) diluted with the same buffer for $1 \mathrm{~h}$ at room temperature. Each incubation was followed by 3 washes in $0.1 \mathrm{M}$ NaPBS containing $0.05 \%$ BSA. The bound peroxidase was visualized using the same procedure described previously except that the DAB was dissolved in NaPB. Sections were mounted and coverslipped as described above.

Slides were examined using brightfield illumination on a Leitz Dialux microscope, and TH-immunostained cells were plotted with the aid of a drawing tube. A cell was considered labeled if its soma was filled with dark reaction product and at least one stained process could be seen emanating from the soma. Cell counts reported here were obtained by totaling the number of TH-IR cells in representative sections through midrostral and caudal Me. The diameter of the long axis of TH-IR cells was determined with a measurement reticle.

The specificity of each of the TH antibodies used in this study has been verified previously $24,69.71 .75$. Additionally, since purified native TH is not available, blocking studies were carried out by preabsorbing the Eugene Tech $\mathrm{TH}$ antiserum with a bacterial lysate containing a $\mathrm{TH} / \beta$-galactosidase fusion protein (Eugene Tech Intl.) for $4 \mathrm{~h}$ at room temperature prior to incubation with the tissue. TH immunostaining was abolished when the primary antiserum was preabsorbed with this fusion protein. No immunostaining was seen when the primary or secondary antiserum was omitted from the respective incubation solution.

\section{RESULTS}

\section{TH immunoreactivity}

A large population of TH-IR neurons consisting of several hundred cells was observed in Me following colchicine administration. The distribution and morphology of these TH-IR neurons were similar in male and female hamsters. The description that follows is based on our analysis of brains from male hamsters.

The TH-IR neurons were concentrated primarily in the midrostral (Fig. 1A) and caudal (Fig. 1B) regions of this nucleus. In contrast, substantially fewer TH-IR cells were observed in $\mathrm{Me}$ of noncolchicine-treated brains (Fig. 1C,D) as reported earlier ${ }^{7,70}$. Both treated and untreated brains contained intensely immunostained neurons in other regions known to contain $\mathrm{TH}$, such as the substantia nigra and locus coeruleus.

A consistent pattern of TH immunolabeling was observed in colchicine-treated brains with all of the $\mathrm{TH}$ antibodies used, but the monoclonal and the Eugene Tech polyclonal antibodies provided the best staining qualitatively with our protocol. Brains from animals treated with all 3 doses of colchicine and perfused with either fixative yielded similar results with regard to the distribution, number and morphology of TH-IR cells. Furthermore, the distribution of TH-IR neurons in regions other than Me appeared to be similar to that previously described in noncolchicine-treated hamster brains $^{70}$ with the exception that we observed a limited number of immunolabeled cells in the bed nucleus of the stria terminalis and the reticular nucleus of the thalamus.

Analysis of the distribution and number of TH-IR neurons revealed that immunolabeled cells were present throughout the rostro-caudal extent of $\mathrm{Me}$ (approximately $1.2 \mathrm{~mm}$ ) in colchicine-treated brains. A few labeled cells were scattered in the rostral-most portion of Me (Fig. 2A), predominantly in the anterodorsal subdivision of the nucleus as defined by Gomez and New$\operatorname{man}^{18}$. A midrostral group of TH-IR neurons appeared approximately $250 \mu \mathrm{m}$ from the rostral tip of Me and extended $300 \mu \mathrm{m}$ caudally (Figs. $1 \mathrm{~A}$ and $2 \mathrm{~B}$ ). In this region, approximately 50 immunostained cells per $40 \mu \mathrm{m}$ section were distributed throughout the anterodorsal and anteroventral subdivisions of $\mathrm{Me}$. In the middle and midcaudal regions of Me, 10 or fewer TH-IR neurons were observed in each section, dispersed throughout the dorsal and ventral subdivisions (Fig. 2C). Another concentrated population of TH-IR neurons was located in the caudal $300 \mu \mathrm{m}$ of Me where only the posterodorsal subdivision remains (Figs. 1B and 2D). Approximately 30 TH-IR cells were found in single sections through this region of the nucleus.

Although TH immunoreactivity in the amygdala was 

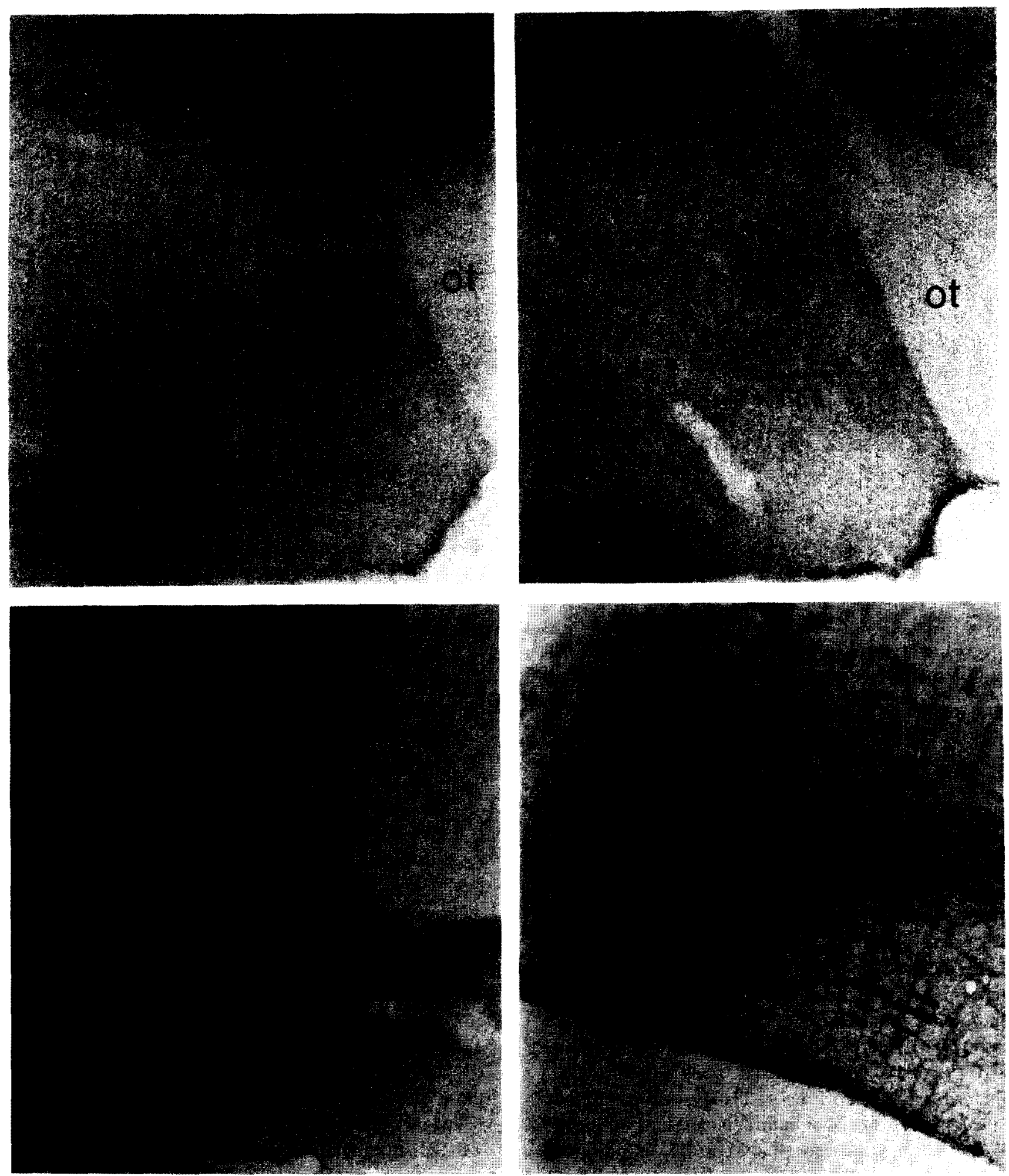

Fig. 4. Photomicrographs $\mathrm{A}$ and $\mathrm{B}$ show that neither the dopamine- $\beta$-hydroxylase (DBH)(A) nor the phenylethanolamine- $N$-methyltransferase (PNMT)(B) antisera labeled any neurons in midrostral Me (level of Fig. 2B). However, neurons of the noradrenergic locus coeruleus from this same brain were intensely labeled with the $\mathrm{DBH}$ antiserum $(\mathrm{C})$, and neurons of the adrenergic $\mathrm{C} 1$ cell group in the ventrolateral medulla were labeled with the PNMT antiserum (D). ot, optic tract; V, fourth ventricle. Bar $=200 \mu \mathrm{m}$.

primarily confined to Me, some immunolabeled cells were also observed in the anterior amygdaloid area, the intra-amygdaloid bed nucleus of the stria terminalis, and the ventromedial region of the central nucleus. The number of immunolabeled neurons in these regions was always less than that observed within Me. 


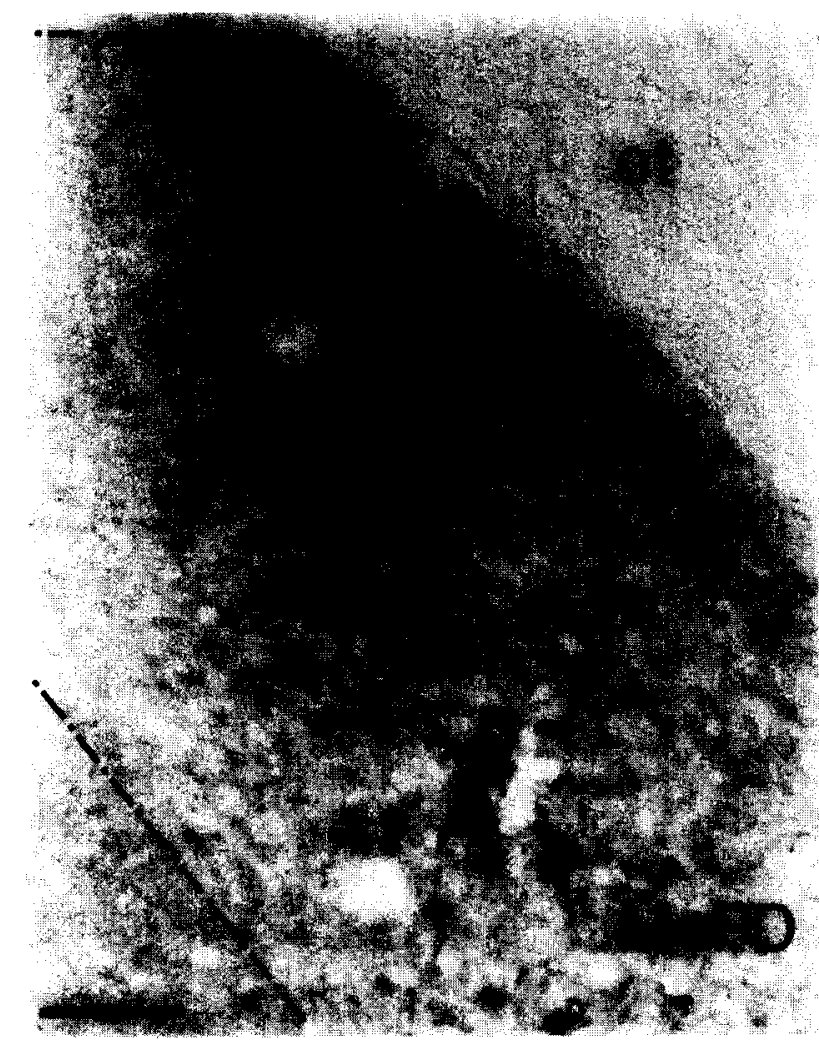

Fig. 5. Photomicrograph of dopamine-IR neurons in caudal Me. The dashed line demarcates the boundary of caudal $\mathrm{Me}$, which consists only of the posterodorsal subdivision. The level of this section corresponds to that of Fig. 2D. MePD, posterodorsal subdivision of Me; ot, optic tract. Bar $=100 \mu \mathrm{m}$.

Morphological analysis revealed that the TH-IR somata in midrostral and caudal Me were small to medium in size (diameter of long axis $=8-20 \mu \mathrm{m}$ ) and were mostly fusiform or ovoid (Fig. 3). Pyramidal and spherical perikarya were seen on occasion. The majority of labeled neurons had two primary dendrites emanating from opposite ends of the soma. Cells with 3 primary dendrites were observed less frequently. The morphology of TH-IR neurons in Me was entirely consistent with the description of Golgi-stained neurons in this nucleus ${ }^{17}$. In midrostral Me, processes of TH-IR neurons often extended into the medial or ventral molecular layer of $\mathrm{Me}$, adjacent to the optic tract (Fig. 3) or the ventral surface of the brain, respectively. In the caudal region of Me, TH-IR neurons occasionally surrounded blood vessels (Fig. 1B,D).

\section{$D B H, P N M T$ and dopamine immunoreactivity}

No cell bodies in Me were immunostained after incubation of colchicine-treated tissue with either the DBH or PNMT antisera (Fig. 4A,B). However, immunolabeling for these enzymes in other areas of the same brain indicated that the staining procedure was successful (Fig. $4 C, D)$.

When the dopamine antiserum was used to immunolabel the glutaraldehyde-fixed tissue, dopamine-IR neurons were observed in the caudal, but not the rostral, region of $\mathrm{Me}$ in colchicine-treated animals (Fig. 5). The location of these dopamine-IR cells corresponded to that of the TH-IR cell group found in the posterodorsal subdivision of $\mathrm{Me}$ at the level of Fig. 2D. As many as 22 dopamine-IR neurons were observed in sections through this area. A few dopamine-IR neurons were also present in the posterodorsal region of midcaudal $\mathrm{Me}$ at the level of Fig. 2C. No dopamine immunostaining was seen in $\mathrm{Me}$ of noncolchicine-treated animals.

\section{DISCUSSION}

The large group of TH-IR neurons in the hamster Me revealed by colchicine administration is a novel population of neurochemically-defined cells that have not been described in this nucleus in other species. Although not all of the species studied to date have received colchicine prior to immunocytochemical staining for TH, i.c.v. administration of $100 \mu \mathrm{g}$ of colchicine into the rat brain ${ }^{33}$, 34,45 or $200 \mu \mathrm{g}$ into the cat brain $^{26}$ has not revealed TH-IR neurons in Me of either species. In addition, we have not observed TH-IR neurons in the rat Me even after injections of $240 \mu \mathrm{g}$ of colchicine (unpublished observations), nor was TH mRNA detected in the rat $\mathrm{Me}$ using in situ hybridization ${ }^{29}$.

This study adds to the growing body of evidence ${ }^{7,10,}$ 15,16.24.26.30,32-34,53,57,64,68,70 for the existence of TH-IR neurons outside of the catecholaminergic cell groups defined in the rat brain by Hökfelt et al. ${ }^{21-23}$. One explanation for the novel expression of $\mathrm{TH}$ in selected cell groups in the hamster brain is that species may differ in the DNA elements that facilitate the expression of the TH gene. In support of this hypothesis, Gandelman et al. ${ }^{14}$ showed that certain regions of DNA which regulate $\mathrm{TH}$ expression are different in rats and humans.

Neither our studies with colchicine-treated brains nor those of Vincent ${ }^{70}$ revealed DBH or PNMT immunolabeling in somata of the hamster telencephalon. Thus, the TH-IR neurons in Me apparently do not produce norepinephrine or epinephrine. The dopamine antiserum, however, labeled a subpopulation of neurons in caudal $\mathrm{Me}$ in the same location as the caudal group of TH-IR cells, suggesting that these caudal TH-synthesizing cells may be dopaminergic. Although no dopamine immunostaining was observed in midrostral Me, the TH-IR neurons in this area may produce dopamine in lower quantities or with a higher rate of turnover. Alternatively, these neurons may synthesize only the immediate pre- 
cursor of dopamine, L-3,4-dihydroxyphenylalanine (LDOPA). The conversion of L-DOPA to dopamine requires aromatic amino acid decarboxylase, an enzyme which may not be present in all TH-containing neurons $^{26,43,48,54,63,71}$.

Although dopamine transmission in a variety of neural systems has been implicated in the sexual arousal of the male rat ${ }^{1,11,46,55,72}$ and $\mathrm{Me}$ is known to facilitate sexual behavior in the male hamster ${ }^{37,38}$, further studies are needed to determine specifically whether the TH-IR cells in $\mathrm{Me}$ of the hamster regulate male mating behavior in this species. Elimination of chemosensory inputs to $\mathrm{Me}^{8}$, $47,56,74$ or lesions of rostral Me itself ${ }^{37}$ completely abolish copulatory behavior in male hamsters. Since the dendrites of TH-IR neurons in midrostal Me extend into the region of the molecular layer containing afferent terminals from the olfactory bulbs (Fig. 3) 37,59 $^{37}$, these neurons are in a position to receive behaviorally essential chemosensory information. Alternatively, the TH-IR neurons described in this report may be involved in non-reproductive functions. In the rat, the Me has been shown to influence ingestive $\mathrm{e}^{42,52,60}$ and aggressive $\mathrm{e}^{31}$, as well as sexual ${ }^{19}$, behaviors.

The finding that TH-IR neurons in caudal Me were occasionally associated with blood vessels (Fig. 1B,D) is reminiscent of observations of monoaminergic perikarya and dendrites in direct apposition to vascular structures in the primate brain ${ }^{12}$. Felten and Crutcher ${ }^{12}$ postulated that these neurons may be influenced by hormones or other blood-borne substances. Neurons in the caudal region of the hamster Me accumulate gonadal hormones, ${ }^{36}$, and their structure is influenced by these steroids. For example, the dendritic morphology of Golgi-stained neurons is altered in caudal Me following castration ${ }^{17}$. The TH-IR neurons associated with blood vessels, therefore, may monitor hormones that influence their morphology and function.

Visualization of the full extent of the TH-containing cell population in Me apparently requires relatively large doses of colchicine since only a few TH-IR cells were

\section{REFERENCES}

1 Agmo, A. and Fernandez, H., Dopamine and sexual behavior in the male rat: a reevaluation, $J$. Neural Transm., 77 (1989) 21-37.

2 Benno, R.H., Tucker, L.W., Joh, T.H. and Reis, D.J., Quantitative immunocytochemistry of tyrosine hydroxylase in rat brain. II. Variations in the amount of tyrosine hydroxylase among individual neurons of the locus coeruleus in relationship to neuronal morphology and topography, Brain Research, 246 (1982) 237-247.

3 Caffe, A.R., Van Leeuwen, F.W. and Luiten, P.G., Vasopressin cells in the medial amygdala of the rat project to the lateral septum and ventral hippocampus, J. Comp. Neurol., 261 (1987) $237-252$. detected without the drug treatment, and Davis and Macrides ${ }^{7}$ reported that the administration of $10-50 \mu \mathrm{g}$ of colchicine had no effect on $\mathrm{TH}$ immunostaining in Me. It is possible that the administration of colchicine may induce or increase the expression of TH messenger RNA (mRNA) in these cells. Intracerebroventricular injections of colchicine have been reported to alter the mRNA levels for several neuropeptides ${ }^{4,5,28}$ and neurotransmitter-synthesizing enzymes, including $\mathrm{TH}^{5}$, in various regions of the rat brain.

On the other hand, the observation of TH-IR neurons in $\mathrm{Me}$ of noncolchicine-treated animals in the present study (Fig. 1C,D), as well as in previous studies ${ }^{7,70}$, supports the conclusion that some cells of the hamster $\mathrm{Me}$ normally express sufficient quantities of $\mathrm{TH}$ to be immunocytochemically detectable. However, immunostainable quantities of this protein may accumulate in the somata of other cells only after the disruption of microtubular transport. This hypothesis is supported by the demonstration that different levels of TH are expressed in separate subpopulations of neurons within the same brain region, as in the substantia nigra ${ }^{73}$ and the locus coeruleus ${ }^{2}$.

Finally, preliminary studies in our laboratory using in situ hybridization indicate that TH mRNA is expressed in $\mathrm{Me}$ of both colchicine- and noncolchicine-treated hamster brains. These preliminary data support the interpretation of the immunocytochemical studies that colchicine simply inhibits the transport of $\mathrm{TH}$ in this large, species-specific population of neurons capable of TH expression.

Acknowledgements. The authors thank Ms. Sara S. Kollack for the preparation of the female hamster brains and Dr. Andrew C. Towle (Eugene Tech Intl.) for providing the bacterial lysate containing a TH $/ \beta$-galactosidase fusion protein. The Morphology Core of the Center for the Study of Reproduction at the University of Michigan provided valuable technical assistance, supported by 1-P30-HD-18258. This work was supported by NIH Grant NS20629 to S.W.N.

4 Ceccatelli, S., Cortes, R. and Hökfelt, T., Effect of reserpine and colchicine on neuropeptide mRNA levels in the rat hypothalamic paraventricular nucleus, Mol. Brain Res., 9 (1991) $57-$ 69.

5 Cortes, R., Ceccatelli, S., Schalling, M. and Hökfelt, T., Differential effects of intracerebroventricular colchicine administration on the expression of mRNAs for neuropeptides and neurotransmitter enzymes, with special emphasis on galanin: an in situ hybridization study, Synapse, 6 (1990) 369-391.

6 Dahlstrom, A., Effect of colchicine on transport of amine storage granules in sympathetic nerves of rat, Eur. J. Pharmacol., 5 (1968) 111-113.

7 Davis, B.J. and Macrides, F.M., Tyrosine hydroxylase immunoreactive neurons and fibers in the olfactory system of the hamster, J. Comp. Neurol., 214 (1983) 427-440. 
8 Devor, M., Components of mating dissociated by lateral olfactory tract transection in male hamsters, Brain Research, 64 (1973) 437-441.

9 Doherty, P.C. and Sheridan, P.J., Uptake and retention of androgen in neurons of the brain of the Golden hamster, Brain Research, 219 (1981) 327-334.

10 Dubach, M., Schmidt, R., Kunkel, D., Bowden, D.M., Martin, R. and German, D.C., Primate neostriatal neurons containing tyrosine hydroxylase: immunohistochemical evidence, Neurosci. Lett., 75 (1987) 205-210.

11 Everitt, B.J., Sexual motivation: a neural and behavioral analysis of the mechanisms underlying appetitive and copulatory responses of male rats, Neurosci. Biobehav. Rev., 14 (1990) 217232.

12 Felten, D.L. and Crutcher, K.A., Neuronal-vascular relationships in the raphe nuclei, locus coeruleus, and substantia nigra in primates, Am. J. Anat., 155 (1979) 467-482.

13 Finley, J.C.W., Maderdrut, J.L., Roger, L.J. and Petrusz, P., The immunocytochemical localization of somatostatin-containing neurons in the rat central nervous system, Neuroscience, 6 (1981) 2173-2192.

14 Gandelman, K.-Y., Coker III, G.T., Moffat, M. and O'Malley, K.L., Species and regional differences in the expression of celltype specific elements at the human and rat tyrosine hydroxylase gene loci, J. Neurochem., 55 (1990) 2149-2152.

15 Gaspar, P., Berger, B., Alavarez, C., Vigny, A. and Henry, J.P., Catecholaminergic innervation of the septal area in man: immunocytochemical study using TH and DBH antibodies, $J$. Comp. Neurol., 241 (1985) 12-33.

16 Gaspar, P., Berger, B., Febvret, A., Vigny, A., Krieger-Poulet, $M$. and Borri-Voltattorni, C., Tyrosine hydroxylase-immunoreactive neurons in the human cerebral cortex: a novel catecholaminergic group?, Neurosci. Lett., 80 (1987) 257-262.

17 Gomez, D.M. and Newman, S.W., Medial nucleus of the amygdala in the Syrian hamster: a quantitative Golgi analysis of gonadal hormonal regulation of neuronal morphology, Anat. Record, in press.

18 Gomez, D.M. and Newman, S.W., Differential projections of the anterior and posterior regions of the medial amygdaloid nucleus in the Syrian hamster, J. Comp. Neurol., in press.

19 Harris, V.S. and Sachs, B.D., Copulatory behavior in male rats following amygdaloid lesions, Brain Research, 86 (1975) 514518.

20 Hökfelt, T., Elde, R.P., Johansson, O., Terenius, L. and Stein, L., The distribution of enkephalin-immunoreactive cell bodies in the rat central nervous system, Neurosci, Lett., 5 (1977) 2531 .

21 Hökfelt, T., Johansson, O., Fuxe, K., Goldstein, M. and Park, D., Immunohistochemical studies on the localization and distribution of monoamine neuron systems in the rat brain. I. Tyrosine hydroxylase in the mes- and diencephalon, Med. Biol. 54 (1976) 427-453

22 Hökfelt, T., Johansson, O., Fuxe, K., Goldstein, M. and Park, D., Immunohistochemical studies on the localization and distribution of monoamine neuron systems in the rat brain. II. Tyrosine hydroxylase in the telencephalon, Med. Biol., 55 (1977) 21-40.

23 Hökfelt, T., Martensson, R., Björklund, A., Kleinau, S. and Goldstein, M., Distributional maps of tyrosine-hydroxylase-immunoreactive neurons in the rat brain. In A. Björklund and T. Hökfelt (Eds.), Handbook of Chemical Neuroanatomy, Vol. 2, Classical Transmitters in the CNS, Part I, Elsevier, Amsterdam, 1984, pp. 277-379.

24 Hornby, P.J., Piekut, D.T. and Demski, L.S., Localization of immunoreactive tyrosine hydroxylase in the goldfish brain, $J$. Comp. Neurol., 261 (1987) 1-14.

25 Khachaturian, H., Lewis, M.E., Hollt, V. and Watson, S.J., Telencephalic enkephalinergic systems in the rat brain, $J . \mathrm{NeU}$ rosci., 3 (1983) 844-855.

26 Kitahama, K., Geffard, M., Okamura, H., Nagatsu, I., Mons,
N. and Jouvet, M., Dopamine- and DOPA-immunoreactive neurons in the cat forebrain with reference to tyrosine hydroxylase-immunohistochemistry, Brain Research, 518 (1990) 83-94.

27 Kitahama, K., Okamura, H., Goldstein, M., Nagatsu, I., Berod, A. and Jouvet, M., A new group of tyrosine hydroxylase-immunoreactive neurons in the cat thalamus, Brain Research, 478 (1989) 156-160.

28 Kiyama, H. and Emson, P.C., Colchicine-induced expression of proneurotensin mRNA in rat striatum and hypothalamus, $\mathrm{Mol}$. Brain Res., 9 (1991) 353-358.

29 Kiyama, H., Emson, P.C. and Ruth, J., Distribution of tyrosine hydroxylase mRNA in the rat central nervous system visualized by alkaline phosphatase in situ hybridization histochemistry, Eur. J. Neurosci., 2 (1990) 512-524.

30 Kohler, C., Everitt, B.J., Pearson, J. and Goldstein, M., Immunohistochemical evidence for a new group of catecholaminecontaining neurons in the basal forebrain of the monkey, Neurosci. Lett., 37 (1983) 161-166.

31 Koolhaas, J.M., Van den Brink, T.H.C., Roozendaal, B, and Boorsma, F., Medial amygdala and aggressive behavior: interaction between testosterone and vasopressin, Aggress. Behav., 16 (1990) 223-229.

32 Kordower, J.H., Sladek, J.R., Fiandaca, M.S., Bing, G. and Gash, D.M., Tyrosine hydroxylase-immunoreactive somata within the primate subfornical organ: species specificity, Brain Research, 461 (1988) 221-229.

33 Kosaka, T., Hama, K. and Nagatsu, I., Tyrosine hydroxylaseimmunoreactive intrinsic neurons in the rat cerebral cortex, Exp. Brain Res., 68 (1987) 393-405

34 Kosaka, T., Kosaka, K., Hataguchi, Y., Nagatsu, I., Wu, J.-Y. and Ottersen, O.P., Catecholaminergic neurons containing GABA-like and/or glutamic acid decarboxylase-like immunoreactivities in various brain regions of the rat, Exp. Brain Res., 66 (1987) $191-210$.

35 Kreutzberg, G.W., Neuronal dynamics and axonal flow, IV. Blockage of intra-axonal transport by colchicine, Proc. Natl. Acad. Sci. U.S.A., 62 (1969) 722-728.

36 Krieger, M.S., Morrell, J.I. and Pfaff, D.W., Autoradiographic localization of estradiol-concentrating cells in the female hamster brain, Neuroendocrinology, 22 (1976) 193-205.

37 Lehman, M.N. and Winans, S.S., Vomeronasal and olfactory pathways to the amygdala controlling male hamster sexual behavior: autoradiographic and behavioral analyses, Brain $R e$ search, 240 (1982) 27-41.

38 Lehman, M.N., Winans, S.S. and Powers, J.B., Medial nucleus of the amygdala mediates chemosensory control of male hamster sexual behavior, Science, 210 (1980) 557-560.

39 Levitt, M., Spector, S., Sjoerdsma, A. and Udenfriend, S., Elucidation of the rate-limiting step in norepinephrine biosynthesis in the perfused guinea-pig heart, J. Pharmacol, Exp. Ther., 148 (1965) $1-8$

40 Ljungdahl, A., Hökfelt, T. and Nilsson, G., Distribution of substance P-like immunoreactivity in the central nervous system of the rat. I. Cell bodies and terminals, Neuroscience, 3 (1978) 861-943.

41 Loren, I., Emson, P.C., Fahrenkrug, J., Björklund, A., Alumets, J., Hakanson, R. and Sundler, F., Distribution of vasoactive intestinal polypeptide in the rat and mouse brain, $\mathrm{Neu}$ roscience, 4 (1979) 1953-1976.

42 Massi, M., Gentili, L., Perfumi, M., de Caro, G. and Schulkin, $\mathbf{J}$., Inhibition of salt appetite in the rat following injections of tachykinins into the medial amygdala, Brain Research, 513 (1990) $1-7$.

43 Meister, B., Hökfelt, T., Steinbusch, H.W.,., Skagerberg, G., Lindvall, O., Geffard, M., Joh, T.H., Cuello, A.C. and Goldstein, M., Do tyrosine hydroxylase-immunoreactive neurons in the ventrolateral arcuate nucleus produce dopamine or only L-DOPA?, J. Chem. Neuroanat., 1 (1988) 59-64.

44 Miceli, M.O., Van der Kooy, D., Post, C.A., Della-Fera, M.A. and Baile, C.A., Differential distributions of cholecystokinin in 
hamster and rat forebrain, Brain Research, 402 (1987) 318-330.

45 Milner, T.A., Joh., T.H. and Pickel, V.M., Tyrosine hydroxylase in the rat parabrachial region: ultrastructural localization and extrinsic sources of immunoreactivity, J. Neurosci., 6 (1986) 2585-2603.

46 Mitchell, J.B. and Stewart, J., Effects of castration, steroid replacement, and sexual experience on mesolimbic dopamine and sexual behaviors in the male rat, Brain Research, 491 (1989) 116-127.

47 Murphy, M. and Schneider, G.E., Olfactory bulb removal eliminates mating behavior in the male golden hamster, Science, 167 (1970) 302-303.

48 Nagatsu, I., Komori, K., Takeuchi, T., Sakai, M., Yamada, K. and Karasawa, N., Transient tyrosine hydroxylase-immunoreactive neurons in the region of the anterior olfactory nucleus of pre- and postnatal mice do not contain dopamine, Brain Research, 511 (1990) 55-62.

49 Nagatsu, T., Levitt, M. and Udenfriend, S., Tyrosine hydroxylase: the initial step in norepinephrine biosynthesis, J. Biol. Chem., 239 (1964) 2910-2917.

50 Neal, C.R. and Newman, S.W., Prodynorphin peptide distribution in the forebrain of the Syrian hamster and rat: a comparative study with antisera against dynorphin $\mathrm{A}$, dynorphin $\mathrm{B}$, and the C-terminus of the prodynorphin precursor molecule, $J$. Comp. Neurol., 288 (1989) 353-386.

51 Neal, C.R., Swann, J.M. and Newman, S.W., The colocalization of substance $P$ and prodynorphin immunoreactivity in neurons of the medial preoptic area, bed nucleus of the stria terminalis and medial nucleus of the amygdala of the Syrian hamster, Brain Research, 496 (1989) 1-13.

52 Nitabach, M.N., Schulkin, J. and Epstein, A.N., The medial amygdala is part of a mineralocorticoid-sensitive circuit controlling $\mathrm{NaCl}$ intake in the rat, Behav. Brain Res., 35 (1989) 127134.

53 Northcutt, R.G., Reiner, A. and Karten, H.J., Immunohistochemical study of the telencephalon of the spiny dogfish, Squalus acanthias, J. Comp. Neurol., 277 (1988) 250-267.

54 Okamura, H., Kitahama, K., Nagatsu, I. and Geffard, M., Comparative topography of dopamine- and tyrosine hydroxylase-immunoreactive neurons in the rat arcuate nucleus, Neurosci. Lett., 95 (1988) 347-353.

55 Pfaus, J.G., Damsma, G., Nomikos, G,G., Wenkstern, D.G., Blaha, C.D., Phillips, A.G. and Fibiger, H.C., Sexual behavior enhances central dopamine transmission in the male rat, Brain Research, 530 (1990) 345-348.

56 Powers, J.B. and Winans, S.S., Vomeronasal organ: critical role in mediating sexual behavior of the male hamster, Science, 187 (1975) 961-963.

57 Reiner, A. and Northcutt, R.G., An immunohistochemical study of the telencephalon of the African lungfish, Protopterus annectens, J. Comp. Neurol., 256 (1987) 463-481.

58 Roberts, G.W., Woodhams, P.L., Polak, J.M. and Crow, T.J., Distribution of neuropeptides in the limbic system of the rat: the amygdaloid complex, Neuroscience, 7 (1982) 99-131.

59 Scalia, F. and Winans, S.S., The differential projections of the olfactory bulb and accessory olfactory bulb in mammals, $J$. Comp. Neurol., 161 (1975) 31-56.

60 Schulkin, J., Marini, J. and Epstein, A.N., A role for the medial region of the amygdala in mineralocorticoid-induced salt hunger, Behav. Neurosci., 103 (1989) 178-185.

61 Simerley, R.B. and Swanson, L.W., Castration reversibly alters levels of cholecystokinin immunoreactivity within cells of three interconnected sexually dimorphic forebrain nuclei of the rat,
Proc. Natl. Acad. Sci. U.S.A., 84 (1987) 2087-2091.

62 Simerly, R.B., Swanson, L.W. and Gorski, R.A., The distribution of monoaminergic cells and fibers in a periventricular preoptic nucleus involved in the control of gonadotropin release: immunohistochemical evidence for a dopaminergic sexual dimorphism, Brain Research, 330 (1985) 55-64.

63 Skagerberg, G., Meister, B., Hökfelt, T., Lindvall, O., Goldstein, M., Joh, T. and Cuello, A.C., Studies on dopamine-, tyrosine hydroxylase- and aromatic L-amino acid decarboxylasecontaining cells in the rat diencephalon: comparison between formaldehyde-induced histofluorescence and immunofluorescence, Neuroscience, 24 (1988) 605-620.

64 Smeets, W.J.A.J. and Steinbusch, H.W.M., New insights into the reptilian catecholaminergic systems as revealed by antibodies against the neurotransmitters and their synthetic enzymes, J. Chem. Neuroanat., 3 (1990) 25-43.

65 Sofroniew, M.W., Vasopressin- and neurophysin-immunoreactive neurons in the septal region, medial amygdala and locus coeruleus in colchicine-treated rats, Neuroscience, 15 (1985) 347-358.

66 Sternberger, L.A., Hardy, P.H., Cuculis, J.J. and Meyer, H.G., The unlabeled antibody enzyme method of immunocytochemistry: preparation and properties of soluble antigen-antibody complex (horseradish peroxidase-antiperoxidase) and its use in identification of Spirochetes, J. Histochem. Cytochem., 18 (1970) 315-333.

67 Swann, J.M. and Newman, S.W., Effect of castration and testosterone treatment on substance $\mathrm{P}$ levels within the vomeronasal pathway of the male golden hamster, Soc. Neurosci. Abstr., 13 (1987) 1576.

68 Tashiro, Y., Sugimoto, T., Hattori, T., Uemura, Y., Nagatsu, I., Kikuchi, H. and Mizuno, N., Tyrosine hydroxylase-like immunoreactive neurons in the striatum of the rat, Neurosci. Lett., 97 (1989) 6-10.

69 Uchida, K., Ishii, A., Kaneda, N., Toya, S., Nagatsu, T. and Kohsaka, S., Tetrahydrobiopterin-dependent production of L-DOPA in NRK fibroblasts transfected with tyrosine hydroxylase cDNA: future use for intracerebral grafting, Neurosci. Lett., 109 (1990) 282-286.

70 Vincent, S.R., Distributions of tyrosine hydroxylase-, dopamine- $\beta$-hydroxylase-, and phenylethanolamine- $N$-methyltransferase-immunoreactive neurons in the brain of the hamster (Mesocricetus auratus), J. Comp. Neurol., 268 (1988) 584-599.

71 Vincent, S.R. and Hope, B.T., Tyrosine hydroxylase containing neurons lacking aromatic amino acid decarboxylase in the hamster brain, J. Comp. Neurol., 295 (1990) 290-298.

72 Warner, R.K., Thompson, J.T., Markowski, V.P., Loucks, J.A., Bazzett, T.J., Eaton, R.C. and Hull, E.M, Microinjection of the dopamine antagonist cis-flupenthixol into the MPOA impairs copulation, penile reflexes and sexual motivation in male rats, Brain Research, 540 (1991) 177-182.

73 Weiss-Wunder, L.T. and Chesselet, M.-F., Subpopulations of mesencephalic dopaminergic neurons express different levels of tyrosine hydroxylase messenger RNA, J. Comp. Neurol., 303 (1991) 478-488.

74 Winans, S.S. and Powers, J.B., Olfactory and vomeronasal deafferentation of male hamsters: histological and behavioral analyses, Brain Research, 126 (1977) 325-344.

75 Wolf, M.E., LeWitt, P.A., Bannon, M.J., Dragovic, L.J. and Kapatos, G., Effect of aging on tyrosine hydroxylase protein content and the relative number of dopamine nerve terminals in human caudate, J. Neurochem., 56 (1991) 1191-1200. 